\title{
Evolution of the Clinical and Epidemiological Knowledge about Chagas Disease 90 Years After its Discovery
}

\author{
Aluízio Prata \\ Faculdade de Medicina do Triângulo Mineiro, Caixa Postal 118, 38001-970 Uberaba, MG, Brasil
}

Three different periods may be considered in the evolution of knowledge about the clinical and epidemiological aspects of Chagas disease since its discovery: (a) early period concerning the studies carried out by Carlos Chagas in Lassance with the collaboration of other investigators of the Manguinhos School. At that time the disease was described and the parasite, transmitters and reservoirs were studied. The coexistence of endemic goiter in the same region generated some confusion about the clinical forms of the disease; (b) second period involving uncertainty and the description of isolated cases, which lasted until the 1940 decade. Many acute cases were described during this period and the disease was recognized in many Latin American countries. Particularly important were the studies of the Argentine Mission of Regional Pathology Studies, which culminated with the description of the Romaña sign in the 1930 decade, facilitating the diagnosis of the early phase of the disease. However, the chronic phase, which was the most important, continued to be difficult to recognize; (c) period of consolidation of knowledge and recognition of the importance of Chagas disease. Studies conducted by Laranja, Dias and Nóbrega in Bambuí updated the description of Chagas heart disease made by Carlos Chagas and Eurico Villela. From then on, the disease was more easily recognized, especially with the emphasis on the use of a serologic diagnosis; (d) period of enlargement of knowledges on the disease. The studies on denervation conducted in Ribeirão Preto by Fritz Köberle starting in the 1950 decade led to a better understanding of the relations between Chagas disease and megaesophagus and other visceral megas detected in endemic areas.

Key words: Chagas disease - heart disease - megaesophagus

Three different periods can be considered in the evolution of clinical and epidemiological knowledge about Chagas disease during the 90 years after its discovery: (a) early studies of Chagas disease in Lassance; (b) a period of uncertainty and of reports of isolated cases; (c) a period of consolidation of knowledge and of recognition of Chagas disease as an extensive rural endemic entity; (d) enlargement of knowledges on the disease.

\section{EARLY STUDIES OF CHAGAS DISEASE IN LASSANCE}

For more than one year, while he was working on the prophylaxis of malaria in the Rio das Velhas Valley, before being aware of the existence of the "barbeiro" triatomine, Carlos Chagas became intrigued by a group of patients whose illness did not match any of the diseases in the general known nosologic picture (Chagas 1922), which he defined as an "autonomous morbid entity" (Chagas 1909a). At that time he discovered Trypanosoma cruzi in the triatomine and in the blood of a cat, and differ-

Fax: +55-34-318.5279. E-mail: a-prata@mednet.com.br Received 9 June 1999

Accepted 9 August 1999 entiated it from another trypanosome, minasense, also discovered by him in 1908 .

On April 15, 1909, after detecting the infection in a child on the preceding day, Chagas wrote from Lassance a one-page preliminary note which was published by Brazil-Médico during the subsequent week (Chagas 1909a), announcing the existence of a new human trypanosomiasis transmitted by the "barbeiro". This was the first in the series of publications that marked the beginning of the understanding of the disease that carries his name, which will be analyzed further on. In this preliminary mote he stated that the notions he had about the disease were still quite incomplete. However, he mentioned fever, sub-palpebral and frequently generalized edema, anemia, ganglionic infarctation, organic decadence, and atrophy of development in some children. He stated that children were more frequently involved and, on the basis of the information obtained, that the disease was lethal in some patients, whereas others appeared to become immunized.

Four months later he published a 62 page paper on the morphology and evolutionary cycle of the trypanosome (Chagas 1909b). And one year later, in 1910, he described in more detail the clinical features of the disease, first in a preliminary 
note dated July 15, 1910 (Chagas 1910a), and later at the 1st Conference held at the National Academy of Medicine on October 26 of the same year, published in Brazil-Médico (Chagas 1910b). In the preliminary note of two and a half pages, he stated that there were three modalities of the disease: an acute one and two chronic ones. He reported that in the acute modality the course of the disease is more serious in patients younger than six months, with the occurrence of meningo-encephalitis, and that after one year of age many patients overcome the acute phase and enter the chronic one. He emphasized the easy clinical diagnosis and its confirmation by the detection of the parasite in peripheral blood, followed by the presence of scarce parasites with the disappearance of fever. He pointed out the special characteristic of edema and the considerable tachycardia, not always proportional to the elevation in temperature, and called attention to the normal cardiac rhythm, in contrast to what was observed in the chronic modality of the disease. He mentioned hepatomegaly and the fact that the spleen was always palpable below the costal margin, a fact that rendered this sign useless in the differential diagnosis from malaria. He mentioned the frequency of ocular alterations, simple conjunctivitis, and keratitis. He soon perceived the difficulty of diagnosis during the chronic phase, which required the inoculation of guinea pigs. The difficulties increased with animal contamination with Pneumocystis carinii, detected by Chagas but properly identified by Delanoe and Delanoe (1912). With respect to the two chronic modalities, he related one of them to goiter, although he emphasized the fact that some patients, adults in particular, frequently present disorders of cardiac rhythm, especially bi- and trigeminism with extrasystoles and compensating rests. He commented that this point attracted his attention since the beginning of his research on the disease, and required a long study for the clarification of its mechanism. The other chronic modality was the nervous form, with motility, psychic or language disorders.

At the 1st conference he told the story of the discovery and stated that "the study of this disease involves the curious fact that we started from previous knowledge about the germ, from a detailed study of its biology, only to reach later, based somehow on this same biology, the notion, practically the most important one, that this was the etiologic factor of a human morbid species".

From an epidemiological point of view, Chagas emphasized the extent of the geographic distribution of the disease in Minas Gerais, Mato Grosso and Goiás. He stated that "the poor population lives in huts under the most precarious conditions, with the walls full of numerous cracks that represent colossal nests for the cone-nosed bugs". He mentioned that other "barbeiro" species in addition to megistus transmit the infection. He said that "barbeiros" can be easily transported in luggage from one locality to another and emphasized the danger of this morbid entity being some day taken to large cities in other regions of the country after the establishment of routes of communication. He also stated that when he slept in infested domiciles he kept the light on in the bedroom in order to avoid being attacked by the blood sucking bugs.

With respect to clinical study, he declared that, after he published a preliminary note, he was able to make "new observations and to reason more at length" due "in addition to a more prolonged study, to the opinion of the masters about the way to understand the disease". He was definitely referring here to the renowned clinicians Miguel Pereira, Miguel Couto and Austregesilo, who will be mentioned later on. He used the designation of parasitic thyroiditis created by Miguel Pereira as a synonym of schyzotrypanosis and divided it into acute and chronic infection according to the higher or lower intensity of the morbid elements and to their persistence. The acute infection includes the meningo-encephalic acute form and the common acute forms without cerebral manifestations. He emphasized the diversity of prognosis, ranging from extreme severity in the former to an habitual chronic condition in the latter.

Five forms were distinguished in the chronic phase: pseudomixedematous, mixedematous, nervous, cardiac, and with acute or sub-acute manifestations. Chagas justified the creation of a cardiac form stating that the "disorders of cardiac rhythm are so prominent among the general symptoms of some cases of the disease that we thought it right to create the cardiac form of schyzotrypanosis in order to assign to it patients with this so notable and predominant semiotic phenomenon. Furthermore, in the prognosis of clinical cases with this sign we found a justification to proceed in this way because not infrequently such patients present acute crises of asystole, resulting in death in some cases". Thus, during the year following the discovery of the disease, the cardiac form was created, the most important modality of the chronic phase of the disease. Chagas added that, in addition to their great importance from a clinical and physiopathological viewpoint, the perturbations of cardiac rhythm were impressively frequent and definitely never observed outside this epidemiological condition. He described the disorders of excitability, which he judged to be more frequent, and of conductibility.

Chagas studied the disorders of cardiac rhythm by physical examination of the circulatory appara- 
tus and by recording the beats in the apex of the heart and the jugular and radial pulses with the polygraph of Jacquet. As reported by Laranja (1949), many disorders of conduction could not have been demonstrated by the methods existing at the time of Chagas and the true incidence of conductibility disturbances, which predominate over cardiac excitability, became known only after the electrocardiographic studies conducted in Bambuí.

In 1911, Chagas published two papers, one of them summarizing previous studies and published in the Memórias (Chagas 1911a) and the second presented as a lecture to the National Academy of Medicine (Chagas 1911b). In 1912, Chagas presented a lecture in São Paulo (Chagas 1912) in which he stated that the larvae always became infected when they fed on individuals with parasites in their peripheral blood. He pointed out that the acute infection was difficult to detect and that he had only observed about 20 acute patients as opposed to hundreds of chronic patients. Among Arabs who had recently arrived in an endemic area he detected chronic disease without an apparent acute phase. He pointed out cases of congenital transmission in newborn infants and he autopsied infected fetuses. He stated that there was no cure for the disease.

Since the beginning of his research, he was intrigued by the frequency of arrhythmias among young individuals, with no sign of generalized sclerosis, as he had never observed previously. He described auricular and ventricular extrasystoles, atrioventricular blocks, bradycardia (with observations of less than $30 \mathrm{bpm}$ in five patients), and node rhythm. He pointed out the variants of irregularity in heart rhythm and mentioned that these variants might exist when the organ was relatively sufficient. He called attention to the frequency of sudden death.

He discussed thyroiditis, the involvement of other endocrine glands and the nervous form, in which diplegia was more frequent, with the observation of more than 100 typical cases of cerebral diplegia. Thyroid lesions were constant.

In 1916, in addition to giving a lecture in Buenos Aires (Chagas 1916a), he published two important articles, one on the pathogeny (Chagas 1916b) and the other on the acute phase of the disease (Chagas 1916c). In these papers, Chagas systematized his observations, justified his concepts and emphasized some points. He stated that the disease presented two phases: an acute one and a chronic one. He studied 27 patients with the acute infection and reported that in the acute phase there was the common form of the disease with cardiac involvement, which most of the time went unper- ceived, especially among adults, and the meningoencephalic form. He described fever directly related to the presence of parasites in the circulating blood. He mentioned the ocular involvement occurring in the acute phase, for which, however, he did not know the exact reason. He pointed out dysphagia, which he related to "mal de engasgo", and its possible attribution to T. cruzi. As a rare observation, he cited the curious skin processes, with one case of dark spots intercalating with erythematous vesicles.

He again mentioned the frequency of mixedema in the acute phase owing to hypothyroidism, although he stated that trypanosomes are not found in the thyroid as easily as they are found in the myocardium.

He compared the acute phase to the chronic one, stating that the histopathological process and the parasitic conditions are identical, but what varies is the inflammatory reaction of interstitial tissue, consisting of infiltration of round cells and extensive hypergenesis of fixed cells, while diffuse myocardial sclerosis predominates in chronic patients. With respect to the chronic phase, he did not consider the pseudo-mixedematous or mixedematous form but created the indeterminate chronic form, as a passage form or as a form in which there was no predominant clinical syndrome. He felt that it was not necessary to maintain the concept that the disease in the chronic phase may course with acute exacerbations, which, however, had to be reestablished a few years later.

Chagas declared that the chronic cardiac form had been definitely clarified. He returned to the importance of sudden death, almost instantaneous in young and healthy individuals and discussed its mechanism: acute dilatation of the right ventricle? Atonia? Reflex syncope? Ventricular fibrillation in patients with profound rhythm disorders? He reported rupture of the ventricle, which he related to the thinning of certain areas of the ventricle, which were as fine as paper sheets. He insisted on the existence of the nervous form and on lesions of the endocrine system that might influence the trophic equilibrium and organic development.

He defended the notion that endemic goiter may be linked to trypanosomiasis using pathogenic (mixedema during the acute phase), pathological (localization of the parasite in the thyroid) and epidemiological arguments (where there is trypanosomiasis there is goiter). He argued that, even admitting that goiter was a simultaneous condition and not an element of the disease, the clinical history of the disease would not depend on this debated relationship, with no changes in the clinical and parasitic conception of the disease, which was clearly differentiated from any other nosologic 
entity. He emphasized the high prevalence of the endemia in various regions.

In 1922, Chagas again devoted his attention to the cardiac form in a study of 63 patients in an article published with Eurico Villela (Chagas \& Villela 1922), which has become a classic. They established the primacy of this form of the disease by stating that it represents "the characteristic par excellence of American trypanosomiasis". They stated that its diagnosis could only be made clinically: "there is no way to contest the etiologic reason of all the clinical observations presented here, although in many patients neither a parasitic diagnosis nor a necroscopic verification has been made". They described the symptoms related to the "progressive exhaustion of cardiac activity" such as arterial hypotension, visceral congestion, dyspnea, effort fatigue, murmurs of relative valve insufficiency, diminution of the sounds, alterations in the intensity and amplitude of apical shock, enlarged heart volume "at times reflecting the hypertrophy of the muscle and at others the dilatation of its cavities, or both simultaneously". They mentioned dizziness, syncope and convulsions as being related to arrhythmias; palpitations did not always depend on extrasystoles. With respect to "avexame", no doubt related to the disease but without uniformity, they stated that "vexation does not reflect anything for the semiologist because it reflects everything for the patient". They mentioned that these manifestations may be due to lesions of the intracardiac sensitive nerves. They systematized the alterations of rhythm by distinguishing between the arrhythmias related to nervous influences and those due to myocardial lesions. They established the prevalence and the diagnostic and prognostic value of the different arrhythmias, stating that American trypanosomiasis could be characterized "as the disease of rhythm alterations par excellence, and especially of slow pulse". They studied the influence of atropine and called attention to its paradoxical effect reducing the number of heart beats and its effect on partial A-V blocks. With respect to the course of the disease, they stated that "in general, we can establish the progressive nature of the cardiac affection in the disease", with no possibility of regression. They added that "despite this, a large number of cases remain in a tolerance state for many years, with affected individuals being able to work". Chagas (1928a) later added that when myocarditis is incipient the patients can devote themselves to any type of work and can live to an old age.

Eurico Villela (1923), who always worked with Chagas, emphasized that the dilatation of the right cavities is the major factor responsible for the enlarged volume of the heart and reported the fre- quency of hyperphonesis and unfolding of the 2nd sound in the pulmonary focus, absence of angina attacks and the diagnostic value of the complement fixation reaction of Guerreiro and Machado.

An analysis of the papers cited above permits us to follow the process by which Chagas, using a clear and precise language, acquired his knowledge about the medical entity which he had faced in the hinterland of the State of Minas Gerais. Based on his exceptional ability for the observation and discernment of the complex ensemble of complaints and of the signs of multiple causes, he progressively constructed the basis of the new morbid entity. He soon individualized the acute phase of the disease after verifying the easy diagnostic confirmation based on the detection of the parasite. During the chronic phase, since the resources of serology were not yet available, the confirmation of the diagnosis in vivo depended on uncertain inoculation of guinea pigs. Even so, Chagas was able to identify the trypanosomiasis among other diseases prevalent in the region, especially the cardiac and indeterminate forms, which are the most important ones, and suggested that perhaps the "mal de engasgo" also had the same cause. It is difficult to determine what was most developed in Carlos Chagas, whether his ability for observation or his ability to interpret the facts. Time eventually demonstrated the exactness of his statements, and for this reason his status as an investigator increased over the years. Few of his many statements were not confirmed and all of them were well founded. With respect to the clinical aspects, we cite the etiology of endemic goiter, the nervous forms and the pluriglandular manifestations. Later studies (Azevedo 1933) demonstrated that endemic goiter was concomitant with the trypanosomiasis and not depending on the latter, as Chagas himself eventually admitted when he said that this was "an open question deserving study and insight" (Chagas 1934, Lobo et al. 1962). Even the possibility that in some patients already presenting thyroid deficiency or miopraxis there might be a more marked hypothyroidism at the beginning of the acute phase, which disappeared with remission of this phase, as reported by Chagas, was not confirmed. With respect to involvement of the nervous system, today we know that it exists but possibly not in the manner in which it was described. However, there is still no explanation of how Chagas detected more than 100 typical cases of cerebral diplegia in the small location of Lassance. The pluriglandular alterations also were not confirmed. But Chagas, who used to examine very thoroughly his patients, perceived that some process systemically impaired the human organism when he stated that "this disease represents a new world in pathology, either because 
of the intensity of the perturbations it causes or mainly because of the generalization of the pathogenic processes to almost all the glands of internal secretion" (Chagas 1911a). This was somehow confirmed by the evidence of denervation.

Many years passed before it was accepted that the master lines about the pathology, clinical presentation and epidemiology of Chagas disease had been established by its discoverer with the help of his invaluable collaborators at Manguinhos. The notions about the acute phase and about the cardiac and indeterminate forms of the chronic phase have been barely altered and what Laranja (1949) said about the cardiac form is still valid also for them: they were more expanded than modified. A similar process occurred, to some extent, for the digestive form, which was not limited to the esophagus.

\section{A PERIOD OF UNCERTAINTY AND OF DESCRIPTION OF ISOLATED CASES}

The lack of confirmation of the etiologic relationship between endemic goiter and the typanosomiasis suggested by Chagas, and the doubts about the pathogenic interpretation of many chronic nervous manifestations attributed to Chagas disease, such as paralysis and idiocy, were also extended to other clinical forms of the disease. A considerable divergence of opinions with respect to the importance of the disease occurred simultaneously, leading to a certain disinterest in its study. This was more evident with respect to the chronic forms of the disease, which were more difficult to confirm and which were also those considered by Chagas to be the most important.

A few years after the early studies of Chagas, sporadic reports of acute cases arose in other locations in Minas Gerais and São Paulo and later outside Brazil.

In the 1930 decade, under the guidance of Mazza, the reports of the Missión de Estudios de Patología Regional Argentina (MEPRA) started to appear, with many acute cases also detected, especially in Chile and Uruguay. The number of these reports increased with the valuable contribution made by Romãna (1935), who described and interpreted the "unilateral schyzotrypanosomic conjunctivitis", later denoted "Romãna sign" by Dias and Chagas at a congress held in Tucumã (Dias 1936). The discovery of the Romaña sign was considered by Evandro Chagas and Dias to be the most valuable foreign contribution to the study of Chagas disease, marking the beginning of a new era in the history of the disease (Chagas \& Dias 1941). Only 36 cases of Chagas disease were reported outside Brazil in six countries until 1934. Over the four subsequent years, thanks to the
Romãna sign which permits suspecting the disease at a distance, more than 500 cases were detected in Argentina and about 100 in Uruguay (Dias 1939). The MEPRA studies also revealed other signs about the point of entry of the parasites, i.e., the inoculation chagoma (Mazza et al. 1940). They also showed that metastatic chagomas and genian lipochagomas are of diagnostic value (Mazza et al. 1940, Jörg \& Freire 1961). Villela (1930), when detecting the first cases of the cardiac form outside Lassance, pointed out that clinicians working in the hinterland and foreign investigators did not attribute the proper importance to clinical research for the diagnosis of chronic Chagas disease, especially the cardiopathy. Outside Brazil, the first cases of chronic Chagas heart disease were diagnosed in 1934 in Argentina (Romaña 1934, Mazza 1934). According to the thorough review published by Laranja (1949), 45 cases of chronic Chagas heart disease had been published outside Lassance by 1945 and 137 cases had been published outside Brazil.

Although by 1943 the disease had been detected in 15 countries, interest in the entity continued to be limited to a small group of specialists. Only they were able to identify the disease.

The importance of the disease as a public health problem, as mentioned by Chagas, still awaited demonstration.

\section{PERIOD OF CONSOLIDATION OF THE KNOWLEDGE AND RECOGNITION OF CHAGAS DISEASE AS A MAJOR RURAL ENDEMIC}

The investigations carried out in Bambuí during the 1940 decade had a great impact, facilitating the recognition of Chagas heart disease on the part of general clinicians (Laranja et al. 1948a, Laranja 1953). Serology (Guerreiro \& Machado 1913) was the tool that confirmed the diagnosis of a large number of cases and its credibility was established with the first 250 cases diagnosed parasitologically. Electrocardiography permitted the detection of heart disease and of the oligo or asymptomatic forms, showing that patients with severe cardiac failure or with advanced lesions were the minority in endemic areas. The clinical studies of numerous cases of Chagas disease in Bambuí, followed-up over a certain period of time, brought new elements for the clinical characterization of the disease, with the establishment of evolutionary types of different prognostic significance. It became clear that the electrocardiographic picture of the disease was not detected in similar groups of individuals with other types of heart disease (Laranja et al. 1948b), with emphasis on the highly frequent ventricular estrasystoles, right branch block or auriculo-ventricular blocks, primary $\mathrm{T}$ 
wave alterations and alterations of the initial phase of the ventricular complex (Dias et al. 1945). From a clinical viewpoint, the individualization of this cardiopathy was helped by the different forms of dyspnea, the frequent occurrence of passive liver congestion as an early manifestation of cardiac failure, the easy restoration of the circulatory equilibrium during the first decompensations, the frequent unfolding and accentuation of the 2 nd sound in the pulmonary focus, and the late character of the cardiopathy during the course of the disease, with a slow evolution and a long patient survival (Dias et al. 1945).

The Bambuí findings fully confirmed and updated the descriptions of the cardiac form of the diseases made by Chagas and Villela, as well as the elevated prevalence of infection, as previously pointed out by Chagas. After Bambuí, the characteristics of the disease became clear, with a consequent easy diagnosis.

\section{ENLARGEMENT OF KNOWLEDGES ON CHAGAS DISEASE}

Another milestone in our understanding of the clinical forms of Chagas disease was the recognition of the digestive form, a term created by Rezende (1959). Chagas had already suspected a relationship between "mal de engasgo" and T. cruzi. Many clinicians, especially in the hinterland of the country, believed that the megacolon and megaesophagus were of chagasic origin (Freitas Junior 1950), as indicated by the geographic coincidence and the occurrence of these pathologies in the same individual.

On the other hand, it had long been known that degeneration of the Auerbach and Meissner plexuses occurred in the megaesophagus in general and also in Brazil (Amorim \& Correa Neto 1932). Correia Neto and Etzel demonstrated that megaesophagus was usually associated with megacolon, achalasia of the pylorus and megaureter, with Etzel (1934) actually proposing a systematized disease that he called neuropathy of the autonomic nervous system and that he attributed to vitamin $\mathrm{B}_{1}$ deficiency (Etzel 1939). Oria and Ramos (1949) demonstrated that extensive degenerative lesions were also present in the intracardiac ganglia. However, an interpretation of these findings was still needed. This resulted from the studies by Köberle and collaborators, who established a method for neuronal counting (Köberle et al. 1961) that permitted them to show the systematic destruction of neurons in Chagas disease. The discovery that a reduction in neuron numbers occurred in the territory of the autonomic nervous system (Köberle 1956) not only provided a pathogenic basis for the hypothesis of the chagasic etiology of megas
(Köberle \& Nador 1955), but also opened perspectives for the understanding of other facts and for other findings related to homeostatic equilibrium.

Esophageal radiology and manometry showed that chagasic esophagopathy does not always present with dilatation or symptoms, with megaesophagus being the terminal phase (Rezende et al. 1960). The same occurs with the stomach, duodenum and colon. The greater or lesser destruction of the neurovegetative system is accompanied by abnormalities in carbohydrate, lipid and water-salt metabolism, hormonal regulation, secretory response of the stomach, salivary glands and sweat glands to stimuli, and other functional alterations involving different sectors of the organism Some investigators (Köberle \& Nador 1955) thought this represented the "new world" mentioned by Chagas.

In addition to denervation of the autonomic nervous system, alterations in the peripheral nervous system and in the central nervous system exist in chronic Chagas disease. The changes in the peripheral nervous system are mainly reflected by the reduction or abolition of osteotendinous reflexes. The changes in the central nervous system have not yet been so well individualized. The limits of the chronic nervous form of Chagas disease have not yet been defined.

Chagas (1916b) mentioned that acute or subacute symptoms appeared in some patients with chronic heart disease, with a worsened prognosis. He called this form chronic heart disease with acute exacerbations. Later, he thought it unnecessary to maintain the individuality of this clinical form since he found exacerbations in all chronic forms of the disease. Patients with chronic Chagas heart disease with a worsened course, usually before the age of 30 years, and with necroscopic lesions similar to those of the acute phase have been defined as subacute patients (Araújo et al. 1985, Laranja et al. 1956).

The use of immundepressants, the increase in diseases involving lymphocyte lineages, especially the human acquired immunodeficiency syndrome, and heart transplantation in chagasic patients have led to a clinical picture similar to that of a new acute phase of the disease without the presence of the parasite in peripheral blood and without IgM class antibodies. For this reason, this clinical form, as suggested by Chagas (1916b), started to be referred to as chronic form with acute reactivation.

From the epidemiological point of view, serology is the method used to determine the prevalence of infection. Several surveys have been performed on populations in endemic areas, among conscripts, in blood banks and in other specific groups. Serologic surveys for the determination of the prevalence of Chagas disease were conducted in Colom- 
bia, Chile, Equador, Honduras, Paraguay and Uruguay. A survey at the national level was carried out in Brazil, which permitted the determination of the prevalence of infection in the country as a whole. Similarly, electrocardiographic surveys are the best method available for the evaluation of the morbidity of the disease, i.e., the prevalence of Chagas heart disease. In Brazil, the gradients of the electrocardiograms of chagasic patients range from 0 to $20 \%$ compared to non-chagasic individuals (Macedo et al. 1982).

About epidemiology, we should also mention the importance of transmission of the disease by blood and blood derivative transfusion (Freitas et al. 1952) as revealed by serologic surveys of candidates to blood donors in blood banks (Pellegrino 1949).

At least in Brazil, serologic surveys after the control of the vectorial transmission of the disease have been showing a low importance of congenital transmission.

Some micro-epidemics of Chagas disease (Teotônia, Catole do Rocha, Amazonia) have suggested oral transmission of $T$. cruzi.

In addition to the investigations conducted in Bambuí, Argentina and Venezuela, many longitudinal evolutionary studies have been conducted in Brazil since the 1960 decade, especially in the states of São Paulo, Minas Gerais, Bahia, Goiás, Piauí and Paraíba, which led to a more complete knowledge of the morbidity, lethality and prognosis of Chagas disease.

Clinical observations have demonstrated geographic differences in the prevalence of heart disease, of the digestive form, of congenital transmission, and of the response to specific treatment. There have been debates about whether these differences are due to the environment, to the parasite or to the host. The determination of a possible relationship with different $T$. cruzi strains has been impaired by the lack of standardization of parasite populations.

Chagas mentioned the prevalence of sudden death in certain families and studies on populations in endemic areas have confirmed this fact. The genetic influence on the pathogeny of the clinical forms has been studied but no conclusive results have been obtained thus far.

Better techniques for serologic diagnosis and for blood culture have become available, as well as the polymerase chain reaction. Two drugs have shown a relative efficacy in the etiologic treatment of the disease, benznidazole and nifurtimox. Other advances have been made in the approach to the disease and its treatment, facilitating the management of Chagas heart disease, among them (Anis Rassi, pers. commun.): (1) an implantable artifi- cial heart pacemaker; (2) Holter and ergometry for the detection of transitory disorders of cardiac rhythm and for the evaluation of the therapeutic action of antiarrhythmic drugs; (3) new antiarrhythmic drugs, especially amyodarone, which clearly reduces the occurrence of sudden death; (4) intracardiac electrophysiologic study for the detection of latent disorders of stimulus formation and conduction; (5) echocardiography for the evaluation of ventricular function and for the diagnosis of cavity enlargement, hypokinesia, akinesia, ventricular aneurysm, and intracardiac thrombosis; (6) a search for late potentials, analysis of RR variability and of QT dispersal, and relation of these conditions to sudden death; (7) surgical ablation of arrhythmogenic foci; (8) transcatheter ablation of arrhythmogenic foci; (9) heart transplant; (10) advances in the management of cardiac failure, such as the use of ACE inhibitors; (11) updating of the therapeutic management of atrial fibrillation, mainly aiming at the return to sinus rhythm by means of chemical or electric cardioversion; (12) implant of a cardioversor-defibrillator.

\section{REFERENCES}

Amorim M, Correa Neto A 1932. Histopatologia e patogênese do megaesôfago e mega-reto. An Fac Med S Paulo 8: 101-127.

Araujo RC, Bestetti RB, Godoy RA, Oliveira JS 1985. Chronic Chagas heart disease in children and adolescents: a clinicopathologic study. Int J Cardiol 9: 439-445.

Azevedo AP 1933. Histologia pathologica da glandula thyreoide na forma aguda da molestia de Chagas (Trypanosomose americana). Mem Inst Oswaldo Cruz 27: 93-123.

Chagas C 1908. Trypanosoma minasense. Nota preliminar. Braz Med 22: 471.

Chagas C 1909a. Nova espécie mórbida do homem, produzida por um trypanosoma (trypanosoma Cruzi) (Nota prévia). Bras Med 23: 161.

Chagas C 1909b. Nova tripanozomiaze humana. Estudos sobre a morfolojia e o ciclo evolutivo do Schyzotrypanum cruzi n. gen., n. sp. Mem Inst Oswaldo Cruz 1: 159-218.

Chagas C 1910a. Aspecto clínico geral da nova entidade mórbida produzida pelo Schyzotrypanum cruzi. Braz. Med 24: 263-265.

Chagas C 1910b. Nova entidade mórbida do homem. Braz Med 24: 423-428, 433-437, 443-447.

Chagas C 1911a. Nova entidade mórbida do homem. Rezumo geral de estudos etiológicos e clínicos. Mem Inst Oswaldo Cruz 3: 219-275.

Chagas C 1911b. Moléstia de Carlos Chagas. Conferência realizada em 7 de agosto de 1911, na Academia Nacional de Medicina. Braz Med 25: 340343, 353-355, 361-364, 373-375.

Chagas C 1912. O mal de Chagas. Arch Soc Med Cir S Paulo 3: 34-66.

Chagas C 1916a. Aspectos clínicos y anátomo 
patológicos de la tripanosomiasis americana. $L a$ Prensa Med Argentina 3: 125-127, 137-138, 153159.

Chagas C 1916b. Processos patojenicos da tripanozomiase americana. Mem Inst Oswaldo Cruz 8: 5-36.

Chagas C 1916c. Tripanosomiase americana; forma aguda da doença. Mem Inst Oswaldo Cruz 8: 37-60.

Chagas C 1922. Descoberta do Tripanozoma cruzi e verificação da trypanozomiase americana. Retrospecto histórico. Mem Inst Oswaldo Cruz 15: 67-76.

Chagas C 1928a. A forma cardíaca da trypanosomiase americana. Arch Bras Med 18: 46-56.

Chagas C 1928b. Sur les altérations du coeur dans la trypanosomiase américaine (Maladie de Chagas). Arch Mal Coeur Vaiss 21: 641-655.

Chagas C 1934. Estado atual da trypanosomiase americana. Rev Biol Hyg 5: 58-64.

Chagas C, Villela E 1922. Forma cardíaca da trypanosomiase americana. Mem Inst Oswaldo Cruz 14: 5-61.

Chagas E, Dias E 1941. A propósito do sinal de Romaña. O Hospital 19: 185-189.

Delanoe P, Delanoe E 1912. A propos du Schizotrypanum cruzi. Bull Soc Path Exot 5: 599-602.

Dias E 1936. O "Signal de Romaña" e os novos progressos no estudo da doença de Chagas. Folha Med: 25 de julho.

Dias E 1939. O signal de Romaña e sua influência na evolução dos conhecimentos sobre a moléstia de Chagas. Braz Med 53: 965-970.

Dias E, Laranja FS, Nóbrega G 1946. Doença de Chagas. Mem Inst Oswaldo Cruz 43: 495-581.

Etzel E 1934. Neuropatologia do megaesôfago e megacolo, estudo de 5 casos. An Fac Med S Paulo 10: 383-395.

Etzel E 1939. Distribuição geográfica do megaesôfago megacolon. Estado atual da teoria da avitaminose B1. Estudo de 626 casos. Rev Ass Paul Med 15: 103158.

Freitas JLP, Biancalana A, Amato Neto V, Nussenzweig V, Sonntag R, Barreto JG 1952. Primeiras verificações de transmissão acidental da moléstia de Chagas ao homem por transfusão de sangue. Rev Paul Med 40: 36-40.

Freitas Junior SV 1950. Megacólon e megaesôfago no Brasil Central. Res Clin Cient 19: 411-423.

Guerreiro C, Machado A 1913. Da reação de Bordet e Gengou na moléstia de Carlos Chagas como elemento diagnóstico. Braz Med 27: 225-226.

Jörg M, Freire R 1961. Lipochagomas genianos, lesiones características de la tripanosomiasis cruzi en la primere infancia. Acta Trop 18: 318.

Köberle F 1956. Die Chagaskrankheit eine Erkrankung der neurovegetativa. Peripherie. Wien Kling Wschr 68: 333 .
Köberle F, Nador E 1955. Etiologia e patogenia do megaesôfago no Brasil. Rev Paul Med 47: 643-661.

Köberle G, Penha PD, Köberle F 1961. A peristalsis chagásica do esôfago. An Congresso Intern Doença de Chagas, Rio de Janeiro 2: 717-722.

Laranja FS 1949. Evolução dos conhecimentos sobre a cardiopatia da doença de Chagas. Revisão crítica da literatura. Mem Inst Oswaldo Cruz 47: 605-669.

Laranja FS 1953. Aspectos clínicos da molestia de Chagas. Rev Bras Med 10: 482-491.

Laranja FS, Dias E, Nóbrega G 1948a. Clínica e terapêutica da doença de Chagas. Rev Bras Med 5: 1-26.

Laranja FS, Dias E, Nóbrega G 1948b. Clínica e terapêutica da doença de Chagas. I Formas clínicas. Rev Bras Med 5: 591-596.

Laranja FS, Dias E, Nóbrega G, Miranda A 1956. Chagas disease. A clinical, epidemiologic and pathologie study. Circulation 14: 1035-1060.

Lobo LCG, Fridman J, Rosenthal D, Ulyssea R, Franco S 1962. Interrelationship of endemic goiter and Chagas disease. J Clin Endocrinol Metab 22: 11821186.

Macedo V, Prata A, Silva GR, Castilho E 1982. Prevalência de alterações eletrocardiográficas em chagásicos (informações preliminares sobre o inquérito eletrocardiográfico nacional). Arq Bras Cardiol 38: 261-264.

Mazza S 1934. Casos cronicos de enfermedad de Chagas determinados en Jujuy. MEPRA 18: 3-19.

Mazza S, Freire R, Urcelay G, Miyara S, Basso G, Basso R, Conte D 1940. Chagomas. MEPRA 46.

Oria J, Ramos J 1949. Alterações do metassimpático do coração nos portadores de megaesôfago (cardiospasmo). Arq Bras Cardiol 2: 311-326.

Pellegrino J 1949. Transmissão da doença de Chagas pela transfusão de sangue. Primeiras comprovações sorológicas em doadores e em candidatos a doadores de sangue. Rev Bras Med 6: 297-301.

Prata A 1975. Reunião sobre Diferenças Geográficas na Doença de Chagas, Brasília.

Rezende JM 1959. Forma digestiva da moléstia de Chagas. Rev Goiana Med 5: 193-227.

Rezende JM, Lanar KM, Oliveira AR 1960. Aspectos clínicos e radiológicos da aperistalsis do esôfago. Rev Bras Gastroenterol 12: 247-262.

Romaña C 1934. Comprobación de formas cronicas cardiacas de tripanosomiasis americana en el Norte Santafecino. MEPRA 14: 25-42.

Romaña C 1935. A area de un sintoma inicial de valor para el diagnóstico de forma aguda de la enfermedad de Chagas. MEPRA 22: 16-30.

Villela E 1923. Moléstia de Chagas. Descrição clínica (2a. parte). Folha Medica 4: 41-43.

Villela E 1930. Da ocorrência da doença de Chagas nos hospitais de Belo Horizonte e na população de seus arredores. Folha Med 11: 229-235. 